\title{
Sustainable Finance and Non-Financial Disclosure: The Impact for the Insurance Industry*
}

\author{
Pietro Negri**
}

\begin{abstract}
Consob Regulation has completed the regulatory framework for the so-called non-financial information in Italy. Having more and more concrete, relevant, accurate, reliable and comparable information on the environmental, social and governance (ESG) impact of companies guarantees greater transparency and knowledge of risks for both consumers and investors, thus ensuring a greater stability and reliability of the entire economic and financial system. Non-financial information begins to be part of the "toolbox" not only of the CSR Managers but also of those in charge of assessing business risks, or those who manage the assets and must formulate increasingly informed investment choices. The insurance sector plays a very special role as underwriter but also as long-term investor.
\end{abstract}

Keyword: Non-Financial Information; Environmental, Social and Governance Criteria; Underwriters; Long-Term Investors; Integrated CSR; Global Markets

\section{Reference Framework}

With the recent publication of the Consob Regulation (resolution 20267/2018), the regulatory framework for the so-called Non-financial information has been completed in Italy.

After the transposition of European directive no. 2014/95/EU through legislative decree no. 254/2016, large companies that have reached certain thresholds of turnover and have employed at least 500 employees have to report on the environmental, social and corporate governance impact of their activities (better known as environmental, social, governance criteria - ESG), starting from last spring's shareholders' meeting (Cantino \& Cortese, 2017).

In brief, the non-financial reporting must have, as a minimum content, a description of:

- the business model and organization of activities;

- the policies practiced by the company and the results achieved;

\footnotetext{
* Invited Article

** Head of Sustainability and Corporate governance Department of ANIA - Italian association of insurers (pietro.negri@ania.it).
}

Edited by: University of Milan-Bicocca

ISSN: 1593-0319 Author

Negri, P. (2018). Sustainable Finance and Non-Financial Disclosure: The Impact for the Insurance Industry, Symphonya. Emerging Issues in Management (symphonya.unimib.it), 1, 110126. 
- the main risks related to the aforementioned issues and deriving, inter alia, from the activities of the company, its products, services or business relationships, including the supply chain.

Undertakings must report on the use of energy resources, polluting emissions, environmental and health impacts, social and staff aspects, respect for human rights and the fight against corruption, both active and passive.

The information must then be compared with previous years (where possible) using publicly recognized reporting standards or an independent methodology.

It is a crucial transition for the entire European economic system, which is thus completed by a significant step in the construction of an advanced development system, increasingly less dependent on the energy produced by fossil sources and increasingly more attentive to circular production processes for the entire life cycle of goods and services, from design to the possible recycling and reuse of raw materials used.

This is the main concept to consider when talking about Sustainable development: the need which cannot be postponed anymore, to construct a frame of reference aimed not only to the exigencies of current generations but also and above all, to those of future generations, ensuring decent conditions of life for everyone.

All this taking into account, on the one hand, the limited resources available to the Planet and, on the other, ensuring that economic prosperity, respect for the environment, harmony and social inclusion are considered as a whole and are also considered the basis of the economic system's sustainable development.

The concept of entrepreneurial activity to which we have traditionally been accustomed, which pursues exclusively profit and satisfaction of shareholder expectations, is today strongly questioned by a vision that, instead, interprets it as an economic entity oriented towards private but also public interests through the satisfaction of all the stakeholders involved, in order to build a sustainable economic development system in the medium to long term.

The economic theory used to consider the generation of profit as the sole task of the management of a company and the "Value Creation Theory" was exclusively considered in terms of creation of shareholder value according to a financial and short-term logic. Over time, the creation of value has been gradually enriched by the concept of sustainability to respond to the growing requests for participation, involvement and assumption of responsibility that come from civil society (Rappaport, 1986; Thomas et al., 1996; Freeman, 1984; Freeman \& Velamuri, 2006; Brondoni \& Mosca, 2017; Salvioni \& Gennari, 2017).

As part of this transformation, new models of cooperation between the community and the business world are becoming increasingly important. The business world takes up the role of professional support to sustain actions aimed at satisfying the growing and changing needs of a context in continuous and unstoppable transformation.

The triangulation of companies, institutions and civil society, defined as "circular subsidiarity", represents a new model of civil Welfare, which goes beyond the universalistic model of an intervention exclusively based on the state when considering the implementation of social and environmental policies and policies in support of the sustainable development of the economy. 
New forms of financing the real economy (impact investing, green bonds, individual savings plans, etc.) are added and support new forms of private intervention in meeting widespread and public needs. The definition of collaborative enterprise is increasingly extensive, which renders tangible a business model having, in its relations with stakeholders, its own strategic business factor.

To try to rationalize and render needs and possible actions to be implemented more concrete, in 2015 the Sustainable Development Goals were defined, by the UN General Assembly, to be reached, possibly, by 2030 (Sustainable development goals - SDGs). As is now well known, these are 17 main objectives, declined in as many as 169 actions, which intend to establish a point of reference at global level in the definition of a more sustainable and balanced future of the Earth.

The SDGs are a benchmark recognized by public and private institutions, national and local governments, metropolitan regions and cities and any other subject who freely wants to adopt them to measure their own legislative policies and their activities.

Mostly at European level we are witnessing an important acceleration on these issues.

The EU Commission in its Action Plan for Sustainable Development, presented at the Brussels Conference of 22 March 2018, hopes that the European Union will become a worldwide reference point for sustainable development, also and especially after the US government has chosen not to sign the Paris Agreement of December 2015.

Our continent aims to become a permanent laboratory of good practices because of its deep cultural roots and the need to find new impetus and reason at the very moment when new signs of growth are realized after the recent economic crisis and the following devastating consequences. The crisis placed the recovery of efficiency and the reduction of costs at the centre of the entrepreneurial management.

The first objective declared by the Union is to reduce $\mathrm{CO} 2$ emissions deriving from economic activities, residential consumption and transport and mobility systems, by $80 \%$ between now and 2050 , even if this would lead to exceeding the goal set during the Paris Agreement to maintain the temperature growth within $2^{\circ} \mathrm{C}$ by 2030 . That is why the debate about the need to strongly anticipate the measures needed to put an end to the dependence on fossil energy is still very much alive.

Another element that has influenced the change in the scenario has been the growing influence of stakeholders on the life of companies as a direct consequence of the intensification of general attention towards sustainable development (OECD, 2017).

In this context, having more and more concrete, relevant, accurate, reliable and comparable information on the ESG impact of companies guarantees greater transparency and knowledge of risks for both consumers and investors, thus ensuring a greater stability and reliability of the entire economic and financial system.

The role of financial institutions is unanimously recognized as fundamental by virtue of their characteristics, the business models adopted and the ability to provide resources to the real economy, particularly to the construction of 
increasingly resilient infrastructures that are adaptable to the current climate and social changes.

These are the reasons why, following the signing of the Paris Agreement, the Financial Stability Board created a Task Force to define a series of specific recommendations on climate change, addressed to all financial intermediaries. From its application they can derive much more useful information to guarantee transparency and stability to the markets.

The rapid dissemination of these recommendations convinced the EU Commission to integrate them in its Guidelines, published in June 2017, on the implementation of the already mentioned directive no. 95/2014 on non-financial information.

It is at least twenty years that companies have started to publicly report on their activities towards their stakeholders, be they shareholders, consumers, employees, external collaborators or civil society.

Balance sheets and social or sustainability reports or other similar instruments are now widespread and appreciated as the main channels of communication used by companies to report on the activities undertaken in favour of subjects that are influenced or come into contact with the company itself.

Many companies, including those not covered by the aforementioned EU directive on non-financial information, have provided themselves with internal structures responsible for defining and telling the public about their corporate social responsibility.

But what has been happening in recent years - with an important acceleration after the Paris Agreement and the publication of the SDGs - is that this complete and widespread information, from simple communication tool, is becoming a tool for integrated work in the main activity of the company, whatever sector it belongs to.

Beyond any ethical or moral considerations, the certainty that the integration of non-financial elements and assessments in business strategies is able to produce economic benefits, as well as environmental and social ones, both for the community and the business, is increasingly consolidated.

This is why non-financial information begins to be part of the "toolbox" not only of the CSR managers but also of those in charge of assessing business risks (operational, credit, reputational, physical risks, etc., the so-called Risk assessment) or who manage the assets and must formulate increasingly informed investment choices (Asset allocation) or, finally, those who are required to verify that the company's business is in compliance with the regulations in force (Compliance).

It is precisely for this reason that the EU Commission has announced important news regarding the scope of the European Supervisory Authorities' powers on the financial sector (EBA, ESMA and EIOPA): from now on, in assessing stability requirements and sound and prudent management of supervised individuals, they will have to verify if ESG criteria have been taken into account and in which measure.

What's more, at the Climate Summit held in Paris on December 8 2017, 22 of the largest asset managers, pension funds and insurance companies signed a statement supporting the importance of enhancing transparency and public disclosure of ESG ratings by issuers, in addition to the Financial Rating. The declaration represents a 
significant step towards greater transparency of non-financial information and an important recognition of their "materiality".

The Signatories invited issuers to disclose their ESG rating, thus complementing their financial rating, because they believe that these factors "constitute risk areas that influence the credit quality and the intrinsic value of the companies and that are crucial for the future creation of value". This information contributes to the efficient functioning of the markets, the optimal allocation of capital and the reduction of information asymmetry ${ }^{1}$.

WWF, on the same occasion, published a Climate Guide for investors to align investments with the goal agreed upon in the Paris agreement $\left(\max +1.5^{\circ} \mathrm{C}\right)$ helping in the transition towards renewable energy sources, maximizing the returns and reducing financial risks (WWF, 2017).

It is time now for sustainability to become an integral part of governance models, through the integration of ESG factors into strategic plans and corporate visions (Brondoni, 2014; Mosca \& Civera, 2017). The integration of environmental and social variables into business logic is now recognized as an opportunity for the strategic relaunch of the company, to be fully included in the development strategies.

In this regard, always considering Italy, it is appropriate to refer to the reference in the Corporate Governance Code for listed companies which, mentioning the responsibility of the Board of Directors in defining strategic objectives, also included risks that could jeopardize sustainability in the medium-long term. In the comment of art. 4 of the Code, a reference has been inserted to the possibility of setting up a specific Committee for the monitoring of ESG variables in the context of the internal Board Committees.

An approach of this type enhances a top-down implementation of the issues related to the environmental and social impact in the various business functions: risk management, compliance, asset management, marketing, information technology, human resources.

Only through self-training and the direct commitment of the Board in this process, in fact, can we really proceed with the integration of the Strategic Plan with the Sustainability Plan (which must obviously be "calibrated" on the concept of materiality of the information used, that varies from company to company, depending on the activity practiced in concrete).

Recently the Italian insurance supervisor (IVASS) published a new regulation (no. 38/2018) introducing under art. 4, paragraph 2, the following provision:

"2.The safeguards relating to the corporate governance system cover all types of corporate risk, including the environmental and social ones, generated or suffered, also according to a prospective view and in consideration of the overall solvency needs of the company. Liability is left to the corporate bodies, each according to their respective competences. The organization of corporate activities, as well as the tasks and liabilities of the corporate bodies and functions, must be clearly defined."

There are many advantages that can be generated in the company through the adoption of processes integrated with ESG information:

- a strengthening of the reputation resulting from the company's commitment to respond to collective needs; 
- a greater ability to attract talents and employee retention, which strengthens the intangible capital stock made up of the improved relationship and enhanced trust between the company and external stakeholders;

- avoided costs and reduction of management risks, also through the adoption of innovative solutions, with the strengthening of the research and development sector for a more efficient use of resources;

- a more evident rate of innovation in products and services with a structural reduction in costs, enhanced by greater efficiency of the production process that uses better technologies together with greater productivity of employees satisfied with their role and work;

- bring suppliers to a more responsible growth, contributing to the creation of a more reliable supply chain for the company;

- greater value of products and services, characterized by a positive environmental and social impact;

- integration of adaptability and greater resilience to the consequences of climatic and environmental crises, as well as to economic ones;

- the creation of new areas in the market for the demand for goods and services.

\section{New Risks and the Need to Establish a Public-Private Partnership}

Last January, at the World Economic Forum held in Davos, the results of a survey, addressed to about 1000 experts, were presented. The results highlighted the greatest risks to refer to for the next 10 years. The first presented was the one resulting from the consequences of climate change, both in terms of "physical" and social risk (World Economic Forum, 2018).

At about the same time, the Geneva Association, considered the Think Tank of the sector, published a report on climate change and its implications for the insurance sector and for the global economic system, based on a survey conducted among top managers (The Geneva Association, 2018).

The inability to cope with climate change is considered among the main risk factors for the economy: limited until recently to the scientific field or to the field of social responsibility, only recently the public debate is taking note of the fact that it is a key issue designed to influence the growth and management of vulnerabilities.

Implementing a system that proves to be resilient to the extreme consequences of climate change requires preventive risk management and appropriate adaptation strategies. According to the Swiss Association, one of the most important actions is the coordination between the various sectors involved: the public sector, the private sector, the insurance sector, and infrastructure investors.

Coordination is fundamental but it must be strategically oriented.

In this perspective, public policies - which in some countries intervene after the occurrence of disasters - often prove to be inefficient and inadequate. Furthermore, the protection gap is still very wide and the insurance tool is not as widespread as it should be.

There are difficulties and delays caused by conflicts between the various regulations: lack of choices at local, national and supranational levels, insufficient 
innovation in the "clean" and "green" technologies sector, difficult development of "green" finance.

The Report contains some recommendations regarding financial aspects and adaptation and/or prevention:

- need for coordination of initiatives - public and private, governmental and civil society - in order to manage climate risk;

- promotion of the role of the insurance industry, which must be among the leaders of the transition to a low-carbon economy;

- importance of the realization of partnerships between the public and private sectors in the construction of fundamental infrastructures, which contribute to a greater resilience of the economic systems.

Since 2013 - with the adoption of the European Strategy for adaptation to climate change - the EU Commission has considered the insurance sector to be the most important subject, among those belonging to the financial sector, to accelerate the adaptation and resilience of the entire production system (European Commission, 2013).

However, much remains to be done, because it is true that a European frame of reference is needed to address these issues, but it is also true that these must be declined within each Member State characterized by specific and peculiar geographical, cultural and social differences.

Public action, especially when considering the climatic and social implications, should be increasingly unified and less fragmented so as to be more effective and to manifest a clear and unequivocal message to operators and to all citizens on its will to pursue a more sustainable and resilient economic policy.

But what emerges mostly is the need to have reliable and complete information on risks and investments (Gandini et al., 2014). According to the United Nations Plan of Action on Disaster Risk Reduction (UNISDR, 2017) it is essential that risk prevention, especially risks stemming from climate change (Franzoni \& Pelizzari, 2016), be concretely integrated with the action of the European Commission for the economic development of the Union and the Junker Plan for investments.

\section{The Role of the Insurance Industry in a Changing Environment}

As is well known, the insurance sector plays a very special role in two complementary areas.

In fact, first of all the insurance company carries out a particular productive activity, represented by the systematic assumption of risks potentially capable of determining future and uncertain damage on the part of the insured (physical damage) or their assets.

Risk transfer takes place through the stipulation of a "policy" in which the insurer commits to compensate damage suffered for an event, against payment of an economic fee.

This is called insurance "technical" management, and it takes the form of risktaking activities, the creation and management of the portfolio, the transfer to other companies (reinsurance), the verification of claims and the assessment and settlement of compensation. 
The onset of a (future and uncertain) debt towards its policyholders requires suitable investments of the premiums collected in advance in order to guarantee the economic-patrimonial equilibrium of the company. It is for this reason that the technical management is accompanied by the "asset" management, which consists in the administration, investment and management of the sums deriving from the collection of premiums.

In both roles the insurance business, by its very nature, necessarily requires a sufficient set (or rather, the widest possible) of available information.

Our industry, in fact, is based on mutuality and on the communion of risks that requires large and complete bases of statistical-actuarial series. It is demonstrated by the most advanced economic theories that the availability of information increases both the efficiency of the individual choices of the companies and the overall efficiency of the market. The economic literature shares the opinion that the efficiency of a market depends crucially on the transparency and quality of the information processed (Spencer, 2000; Gnecchi, 2006; De Haan et al., 2009).

To insure means making mutuality and considering insurance coverage a law of large numbers and working on the basis of extensive and complete statisticalactuarial series: it means, therefore, having to put together a quantity of information and related and relevant news to organize and manage a communion of risks.

This stated, it must be stressed, however, that the role of the insurance sector, at least in Italy, has not yet been sufficiently valued, above all for its natural and implicit ability to "understand risks" through their analysis and management.

A more effective and solid partnership with the institutions could concretely trigger a virtuous process. In this direction, the action of the Public Administration could contribute to the definition of adequate and widespread public data platforms, with an ever-increasing evidence of the direct correlation between risk prevention, reduction of moral hazard and a better management of the phase following the occurrence of the event giving rise to the damage: at this latter stage the insurance sector could play a strategic and decisive role for the entire community.

The continuity of production for the companies involved in the earthquake that hit Emilia Romagna has been effectively managed by the insurance companies that, with their intervention, have ensured the survival of companies, even very small ones, that in other contexts would have completely disappeared from the market.

It is possible to create a common alliance between insurers and policyholders and/or subjects, in which the former, taking increasingly into account the ESG criteria in the assessment of risks and, correlatively, in the calculation of premiums, can "reward" the virtuous behaviour held by the latter.

But the insurance sector - formed, as previously pointed out, by institutional investors oriented to the medium-long term - is ready to play its part also as a support to public action in the definition of a general action plan to increase resilience to climatic and social changes.

The insurance savings have, among its characteristics, that of being typically long lasting. It is an aspect that makes it suitable to meet the financing needs of an economy that has to start on a more vigorous growth.

The Individual Savings Plan regulation is an important form of investment towards financing the real economy. Using a Fund for infrastructures, for example, 
with a reallocation of just $2 \%$ of the reserves held by insurance companies, one could obtain access to around 15 billion Euros.

According to CRESME, one billion Euros invested in the energy renovation of buildings could generate about 17,000 new jobs.

However, the intervention of the insurance sector must be included in the broader scope of a public-private action that defines infrastructural interventions able to prevent risks, mitigate the consequences and constitute a valid instrument of awareness for the entire community.

The European Commission, in cooperation with the insurance sector, has launched the NAIAD H2020 project to collect and analyse data and information. The final purpose is to promote the creation of an ecosystem in which new products or insurance investments are realized - to counter the risks arising from floods and drought - in which the prevention, management and resilience measures adopted are taken into account (Nature based solution - NBS) ${ }^{2}$.

Integrating such data with information on the prevention and resilience measures adopted would certainly reduce the incidence of risk, also through the design of new insurance instruments that could use compensation systems based on a parametric approach.

Thanks to the boost of specialized NGOs, the major companies operating in the international maritime sector have recently taken important initiatives in terms of self-regulation, producing a series of proactive efforts aimed at encouraging improvements in environmental management and funding research and development initiatives in order to make ships safer and more sustainable.

In this direction, one of the most important actions taken was that of the "Sustainable Shipping Initiative" (SSI) promoted in 2011 by the Forum for the future in cooperation with some of the world's major carriers, banks, insurers and the WWF. It was the first time that the maritime transport sector joined forces on a global scale with the aim of intervening on sustainability issues.

Using transversal skills and taking advantage of the possible synergies, within the SSI an ad hoc project was developed for the "Super Eco Ship - NYK Eco Ship 2030". After winning the Good Design Award in Japan (2009), the project led to the concrete realization of a concept transport vessel that can be considered as a real "carrier/container of the future".

As a matter of fact, the Eco Ship intervenes on carbon dioxide emissions by reducing the amount of energy needed for propulsion through a decrease in weight and strength of the hull. It is supported by an innovative technological equipment, with fuel cells and renewable energy sources, including solar and wind energy that can reduce harmful emissions without compromising the current transport capacity and speed.

In September 2013, just two years after its launch, the SSI announced the first practical results achieved, especially in ensuring healthier and safer working environments, improving the reputation profile and allowing participating companies to gain the whole community's confidence for the responsible and sustainable approach adopted.

But the project has also contributed to the definition of a new economic model aimed at making financing more accessible to shipowners and charterers to reconvert and develop the energy efficiency of ships, also taking into account 
materials used in construction and the use of sustainable technologies. What working in the field highlighted is that the control of harmful emissions is able to produce benefits to the entire industry of transport and not only to shipowners.

But to what extent can this approach also translate into an insurance benefit?

The insurance industry, thanks to the use of technology, can concretely improve calibration and risk management. A better efficiency and quality in recruitment and management - supported by a robust use of data, information and technology - in addition to improving the service rendered, can encourage the growth of policyholders aware of their direct and immediate importance in preventing risks. Their role is no longer exclusively of "counterpart" but as co-protagonists, together with the insurer, of the process of environmental, social and economic renewal.

On the other hand, it should be noted that Directive no. 2016/97/EU on insurance distribution (IDD) focuses, above all, on improving consumer and retail investor protection by ensuring greater transparency regarding price and product information.

Within the Product Oversight Governance (POG) companies must take into account the interests, objectives and characteristics of customers, defined in special Target markets (TM); to protect these TM, measures must be taken (design, testing, gap analysis, control, revision and distribution) throughout the whole product life cycle.

To assess whether an insurance product is compatible with a group of customers, the company is required to create products aligned with their demands and needs. The TM must be identified at a sufficient level of granularity, on the basis of the characteristics, risk profile, complexity and nature of the product, excluding those customers who have needs and exigencies not compatible with the same TM.

The insurer will therefore have to answer to a series of questions also regarding the determination and congruity of the premium/benefits: are the technical bases used consistent with the TM identified? Have stress tests on the technical bases been carried out to verify that the benefits deriving from the performance connected to the product are in line with the definition of the TM identified? And so on.

It is precisely in this direction that we can search for useful ideas to use ESG criteria in estimating the risk premium and in assessing investments.

What's more, in order to accelerate the renewal process under way and achieve these objectives more fully, certain existing regulatory and cultural barriers must be "removed".

The European insurance law (Solvency II), in particular, is based on the "prudent person" principle in the management of risks and investments (O'Donovan, 2014). Insurers "... shall have in place processes which are proportionate to the nature, scale and complexity of the risks inherent to its business and which enable it to properly identify and assess the risks it faces in the short and long-term and to which it is or could be exposed".

Insurers are among the largest institutional investors in Europe with approximately $€ 10$ tn of assets managed in different investment classes (equities, public and private debt securities, infrastructure, etc.).

In the investment choices, at least the characteristics of the commitments undertaken and their duration, the economic return and the "volatility" of the investment are taken into account. 
However, the legislation requires substantial capital to cover investments, especially when they are medium to long term. And this is why it is a limit to investments in infrastructures that, by their very nature, extend over time.

Reconciling sustainability with financial objectives requires the bridging of the gap between analytical method, financial instruments and process governance, by introducing systems that are able to measure increasingly better and more scientifically the importance of adopting ESG criteria.

Non-financial ESG information is another element of evaluation that increases awareness and knowledge also in investments.

As institutional investors, moreover, through the "voice" that can be exercised in general meetings of issuers in which they have invested, insurers can exercise an "engagement", a "conditioning" on the management of the company in order for them to consider more and more ESG criteria in the production process. Maybe this could also happen through the prediction of payment systems for the variable part of the remuneration (Kostyuk et al., 2016) related to the achievement of sustainability objectives.

\section{The Organization, Management and Use of Non-Financial Information}

The typical approach of non-financial reporting systems is based on the materiality principle: the relevant information to be provided is defined by the reporting company itself on the basis of a materiality analysis related to its business profile, strategies and stakeholders' expectations and to the context in which it operates (Salvioni \& Bosetti, 2014a; Jones et al., 2015; Font et al., 2016; Whitehead, 2017).

Companies in the insurance sector show an increasing quality of the processes activated for the evaluation and identification of the materiality of the information, even if the implicit potential of the ESG information in the business processes is not fully understood yet.

Just recently, ANIA has commissioned the main associated companies a research to verify the level of awareness and use in defining the strategy and business organization of non-financial information as a tool to be used for reporting, risk management and investment choices.

First, the survey shows that the integration of information into the company organization has led to the need to review the processes for their acquisition, involving both the underwriters and the entire distribution chain.

The data acquisition procedures are not yet well structured and automated and the distribution network is not particularly involved yet.

Important in this sense could be the announced issue of a specific delegated regulation by the EU Commission under the MiFID II and IDD directives regarding the distribution of financial and insurance products related to the achievement of not only financial objectives but also environmental and social impact ones. In fact, in this respect there is a growing demand for financial and insurance products intended for retail customers who, in addition to pursuing financial performance targets, also intend to achieve environmental and social objectives. 
The information, in order to be used at company level, required a robust standardization work, by defining suitable assessment and measurement tools.

In this regard, the need immediately emerged to have new skills and professionalism able to integrate the traditional methodologies with completely new assessments that deal with risk (or investment) analysis from a different point of view, enriching the overall evaluation.

The most interesting aspect in the accompanying process that characterized this first phase was the creation of ad hoc working groups of a transversal type among the various company functions, due to the different and complex implications that each area can find in the use of these information.

In general, the most widely used reporting standard in the sector remains the Global Reporting Initiative (GRI - more oriented to pursuing stakeholder expectations), but several companies already issue a report integrated with ESG information, following the standards of the International Integrated Reporting Council (IIRC - whose approach is more attentive to investor needs) (Salvioni \& Bosetti, 2014b).

As required by law, some insurance companies have chosen to include the NonFinancial Statement in a specific section within the management report; others have decided to create a separate statement for the Non-Financial Statement, following two different accounting philosophies.

In organizational terms, companies in the sector have made some significant choices, in some cases by adopting the function of CSR manager as a catalyst for collecting relevant information and preparing the Declaration, while others have preferred to entrust it to the administration and budget function (Chief Financial Officer - CFO) and others to Communication.

In companies that still had not issued a real report before the new regulation entered into force, the role of activator is often assigned to the Compliance function; in more mature realities, Risk management is much more involved in risk analysis and in identifying new business opportunities, due to the specific professionalism of the role.

However, the involvement of the Board of Directors in the definition of strategic plans that also integrate this type of ESG information (Marlow et al., 2012; Salvioni et al., 2016) remains partially limited.

With the clear intention to encourage an increasing involvement and new approaches to the business also through a greater "differentiation", of Gender as well, we are working with the Forum for sustainable finance at a survey, within the Boards of Directors. The purpose is to analyse the gender differences in terms of preferences in the purchase of financial products and, in particular, the propensity to subscribe to sustainable financial and insurance products ${ }^{3}$.

The research also intends to examine the extent to which the gender variable influences elements such as: the perception of financial risks and risk/return profiles, the preference for certain types of advice, the perception of one's financial competence and the themes to which particular importance is attributed to the choice of investments.

Moreover, in a broader perspective, it should be ensured that, at least the largest companies on the stock markets, adopt policies aimed at promoting, within the entire corporate organization, equal treatment of genders and, more generally, 
diversity understood in its various meanings as a fundamental element of company sustainability.

However, we fully understand the importance of increasing knowledge also through specific training sessions that can raise the perception of the members of the Board, both in terms of correct risk definition and capital allocation and as an opportunity to explore new ways of exercising the activity.

For some operators in the sector, ESG information is already relevant in equity investments, through the use of Principles for responsible investment (PRI), created by the United Nations in 2006 with the aim of promoting the diffusion of sustainable and responsible investment among institutional investors.

However, also in real estate management, ESG information is starting to be used: for example, through a green redevelopment of instrumental and income-generating properties. Similarly, the community can be involved in social issues with regard to property management and innovation (sometimes with the help of new technologies), creating new products that take into account the emerging environmental and social needs and reward the virtuous behaviour of the client.

Sustainable risk management combines, in fact, with a growing trend aimed at requiring ever higher environmental and social benefits, from both the end customers and the investors.

The real estate assets, in particular, which in the near future will not present sustainability-oriented features, will become less and less marketable, not meeting demand expectations, and will probably have a reduced market value, an increase in vacancy periods, a heavier operating and maintenance cost structure.

On the other hand, the green properties favour an extension of the useful life of the property, a reduction in operating costs, the minimization of vacancies and the stabilization of a positive return (less influenced, for example, by the fluctuations in price of energy) (Forum per la Finanza Sostenibile, 2014).

These considerations could also influence the policy of determining the insurance premium considering that a "green" property could represent, with the appropriate technical insights, a lower risk index (in fire policies, for example, but perhaps also in those of civil liability).

The questions to ask could go beyond simply knowing the value of the property to be rebuilt in case of a harmful event. In fact, while to define the price of a building you can refer to characteristics not only of a structural type (brightness, number of services, rooms, etc..), for the determination of the premium, however, the evaluation of SE factors could become more and more relevant to the point of affecting also the determination of the premium.

For example, it could be important for risk assessment to know if you are in the presence of possible flood risks or exposed to extreme weather events, or what grade of resilience the Public Administration and the insured have achieved.

Other significant information includes the existence of a public/private partnership "policy" in the management of the territory, the existence of some form of co-management of the building by those who occupy it (energy, water or waste management), the presence of power-generating facilities, and, the existence of a (real) convergence of interests between the tenant and owner in the management of the property. Moreover, it is useful to know if the property is leased to employees 
in the context of a corporate welfare plan or if the rent (or the condominium charges) is linked to the reduction in consumption, and so on.

Some companies seem to have taken this direction. In some insurance products, the adoption of energy and/or production standards, the use of bio-architectural materials in construction and energy efficiency are favoured, in terms of coverage costs and the expansion of guarantees.

In other insurance branches, for example in transport, similar phenomena are observed. A declaration has been recently signed among some insurance companies at a global level in which the signatories commit to fight against illegal fishing in the oceans through education, awareness, risk management and the preparation of innovative insurance products ${ }^{4}$.

Similar considerations have already been tested for other types of risk: for example, in the MTPL (motor third party liability) insurance through the use of the Black box, or in guarantees related to personal risks through the use of wearable devices.

\section{Conclusions}

We are at a turning point and the signs of change are increasingly evident. Everywhere in the world there are growing signs of awareness for the choices to be undertaken, even though a univocal and cohesive direction towards the strategies to be taken to face the change is not yet evident.

Several large insurance companies have announced divestment programs from fossil fuels to direct them towards low-carbon renewable energies. It is an important signal that collects the request for an increasing part of civil society.

However, we also need a strong signal from politics and institutions that takes over the "direction" of the process of change and addresses it in an oriented program. In this sense, the need to stop the consumption of land seems to be inescapable, preferring the regeneration of the existing real estate assets and making sure that the infrastructures are increasingly resilient to climate change.

Initiatives have already been announced to revise the European directive on nonfinancial information in the sense of extending the subjective scope of application to companies with more than 250 employees, as it has already been done in the countries of northern Europe. It is an important signal that could greatly encourage the dissemination of not yet fully understood and used information, which could become very relevant in the analysis of risks and investments in the future.

The financial world expects the European Union to achieve a "taxonomy" of "green and social" investments with the aim of increasing the certainty, transparency and stability of markets. The introduction of a European green label for Green Bonds can only be strongly hoped for, to channel investments towards the infrastructures we need.

Technology is a very important factor supporting sustainability: through the blockchain and smart contracts it is possible to create innovative products and services that reinforce common goals between insurers and policyholders and between insurers and subjects in which to invest ${ }^{5}$. 
Digital technologies - which allow the transmission of large amounts and varieties of data in real time - can radically transform the methods used to classify insured persons according to risk, moving from traditional methodologies to a dynamic and prospective approach. This new approach potentially reconstructs the risk profile of the insured and may foster virtuous dynamics, that can affect the general level of claims experience through the dissemination of prudent and consumer-oriented conducts ${ }^{6}$.

In this regard, the experience gained in other European countries of the "Regulatory sandboxes" would allow to experiment new products that increase the level of awareness on the importance of ESG criteria.

2018 will be a decisive turning point in a positive or negative sense. The lack of a cultural and holistic approach to sustainability remains the main obstacle to be removed. If we succeed in this, we will be more likely to accelerate the process of change necessary to conserve and maintain the resources of our planet over time.

\section{Bibliography}

Brondoni, S. M. (2014). Global Capitalism and Sustainable Growth. From Global Products to Network Globalisation, Symphonya. Emerging Issues in Management (symphonya.unimib.it), (1), 10-31.

http://dx.doi.org/10.4468/2014.1.02brondoni

Brondoni, S.M., \& Mosca, F. (2017). Ouverture de 'Integrated Corporate Social Responsibility', Symphonya. Emerging Issues in Management (symphonya.unimib.it), (1), 1-6.

http://dx.doi.org/10.4468/2017.1.01ouverture

Cantino, V., \& Cortese, D. (2017). Integrated Report System: Purposes and Benefits of the Italian Law. Symphonya. Emerging Issues in Management (symphonya.unimib.it), (1), 83-94.

De Haan, J., Oosterloo, S., \& Schoenmaker, D. (2009). European Financial Markets and Institutions. Cambridge: Cambridge University Press.

European Commission (2013). An EU Strategy on Adaptation to Climate Change. COM(2013) 216 final.

Font, X., Guix, M., \& Bonilla-Priego, M. J. (2016). Corporate Social Responsibility in Cruising: Using Materiality Analysis to Create Shared Value. Tourism Management, 53, 175-186.

http://dx.doi.org/10.1016/j.tourman.2015.10.007

Forum for the Future (2011). Sustainable Shipping Initiative. The Case for Action.

Forum per la Finanza Sostenibile (2014). Linee Guida per l'Investimento Immobiliare Sostenibile e Responsabile.

Franzoni, S., \& Pelizzari, C. (2016). Weather Risk Management in Tourism Industry, Symphonya. Emerging Issues in Management (symphonya.unimib.it), (1), 45-55.

http://dx.doi.org/10.4468/2016.1.05franzoni.pelizzari

Freeman, R. E. (1984). Strategic Management. A Stakeholder Approach. Boston: Pitman.

Freeman, R. E., \& Velamuri, S. R. (2006). A New Approach to CSR: Company Stakeholder Responsibility, in Kakabadse A., Morsing M. (eds), Corporate Social Responsibility. London: Palgrave Macmillan. http://dx.doi.org/10.1057/9780230599574_2

Gandini, G., Bosetti, L., \& Almici, A. (2014). Risk Management and Sustainable Development of Telecommunications Companies. Symphonya. Emerging Issues in Management (symphonya.unimib.it), (2), 16-29.

http://dx.doi.org/10.4468/2014.2.03gandini.bosetti.almici 
Gnecchi, F. (2006). Corporate Governance Communications, Symphonya. Emerging Issues in Management (symphonya.unimib.it), (1), 2006, 47-61.

http://dx.doi.org/10.4468/2006.1.04gnecchi

Jones, P., Comfort, D., \& Hillier, D. (2015). Materiality and External Assurance in Corporate Sustainability Reporting. Property Management, 33(5), 430-450.

http://dx.doi.org/10.1108/PM-03-2015-0014

Kostyuk, A., Stiglbauer, M., \& Govorun, D. (2016). The Theory and Practice of Directors' Remuneration: New Challenges and Opportunities. Emerald: Bingley.

Marlow, D. R., Moglia, M. , Beale, D. J., \& Stenstromer, A. (2012), Embedding Sustainability into a Utility’s Business Culture. Journal - American Water Works Association, 104, E121-E126. http://dx.doi.org/10.5942/jawwa.2012.104.0026

Mosca, F., \& Civera, C. (2017). The Evolution of CSR: An Integrated Approach, Symphonya. Emerging Issues in Management (symphonya.unimib.it), (1), 16-35. http://dx.doi.org/10.4468/2017.1.03mosca.civera

O’Donovan, G. (2014). Solvency II: Stakeholder Communications and Change. Farnham, Surrey, UK: Routledge.

OECD (2017). Investment Governance and the Integration of Environmental, Social and Governance Factors.

Rappaport, A. (1986). Creating Shareholder Value: A Guide for Managers and Investors. New York: The Free Press, Simon \& Schuster Inc.

Salvioni, D. M., \& Bosetti, L. (2014a). Stakeholder Engagement and Integrated Reporting: Evidence From the Adoption of the IIRC Framework. Journal of Strategic and International Studies, 9(3), 78-89.

Salvioni, D. M., \& Bosetti, L. (2014b). Sustainable Development and Corporate Communication in Global Markets, Symphonya. Emerging Issues in Management (symphonya.unimib.it), (1), 1-19. http://dx.doi.org/10.4468/2014.1.03salvioni.bosetti

Salvioni, D. M., Gennari, F., \& Bosetti, L. (2016). Sustainability and Convergence: The Future of Corporate Governance Systems? Sustainability, 8(11), 1203.

http://dx.doi.org/10.3390/su8111203

Salvioni, D.M. \& Gennari, F. (2017). CSR, Sustainable Value Creation and Shareholder Relations, Symphonya. Emerging Issues in Management (symphonya.unimib.it), 1, 36-49.

http://dx.doi.org/10.4468/2017.1.04salvioni.gennari

Spencer, P. D. (2000). The Structure and Regulation of Financial Markets. Oxford: Oxford University Press.

The Geneva Association (2018). Climate Change and the Insurance Industry: Taking Action as Risk Managers and Investors. Perspectives from $C$-level executives in the insurance industry. The Geneva Association - The International Association for the Study of Insurance Economics.

Thomas, H., Heene, A., \& Sanchez, R. (eds.) (1996). Dynamics of Competence-Based Competition: Theory and Practice in the New Strategic Management. Research Collection Lee Kong Chian School of Business. Pergamon, Elsevier Science.

UNISDR (2017). United Nations Plan of Action on Disaster Risk Reduction for Resilience. Towards a Risk-informed and Integrated Approach to Sustainable Development.

Whitehead, J. (2017). Prioritizing Sustainability Indicators: Using Materiality Analysis to Guide Sustainability Assessment and Strategy. Business Strategy and the Environment, 26(3), 399-412. http://dx.doi.org/10.1002/bse.1928

World Economic Forum (2018). The Global Risks Report 2018, $13^{\text {th }}$ Edition. WEF, Geneva.

WWF (2017). WWF Climate Guide to Asset Owners: Aligning Investment Portfolios with the Paris Agreement. Brussels. 
(c) SYMPHONYA Emerging Issues in Management, n. 1, 2018

symphonya.unimib.it

\section{Notes}

${ }^{1}$ The 22 co-signatories' Declaration on "Towards a wider application of non-financial rating" (8 December 2017) is available at the following link: http://www.vigeo-eiris.com/wpcontent/uploads/2017/12/20171208_Declaration-towards-a-wider-application-of-non-financialrating-081220...pdf

${ }^{2}$ The H2020 NAIAD project: Nature Insurance Value: Assessment and Demonstration, 2016-2019; http://www.naiad2020.eu/

${ }^{3}$ http://finanzasostenibile.it/forum-finanza-sostenibile-eng/

${ }^{4}$ To follow-up these issues see: Marine Aviation \& Transport Insurance Review, July 2016, n. 3, year VI, page 7 ff. See also OCEANA, Assisting Ocean Stewardship Through Marine Insurance, available at http://eu.oceana.org/en/assistingocean-stewardship-through-marine-insurance.

${ }^{5}$ "In the insurance market the impact of digital innovation, operates at various levels of the value chain [...] Results may be a greater efficiency and cost reduction in corporate operations, innovation in insurance products, the development of retail premiums [...] new ways of distribution and post-sale assistance with the use of connected devices, the entry of new operators and revision of the business model of undertakings already operating». Intervention by S. Rossi, IVASS President, 15 December 2017. https://www.ivass.it/pubblicazioni-e-statistiche/pubblicazioni/attsem-conv/2017/conv-1512/index.html

${ }^{6}$ Public Hearing of M. B. Farina, ANIA President, at the Italian Parliament, December 2017. http://webtv.camera.it/evento/12353 